\title{
Experimental Geotechnical Characterization Campaign of the Matam Soil for Lithology: Application to the Study of Supports of the Balterdi Bridge
}

\author{
Abdoulaye Diedhiou', Libasse Sow ${ }^{1 *}(\mathbb{D})$, Gorgui Thierno Yoro Diouf ${ }^{2}$, Mbene Diop', \\ Ndeye Mareme Diop ${ }^{1}$ \\ ${ }^{1}$ Civil Engineering Department, Higher Polytechnic School, Cheikh Anta Diop University of Dakar, Dakar, Senegal \\ ${ }^{2}$ Technosol Engineering Laboratory, Dakar, Senegal \\ Email: abdoulaye.diedhiou@esp.sn, ^libasse.sow@esp.sn, gty.diouf@technosol-ingenierie.com, mbenediop1@outlook.fr, \\ diopndeyemareme6@gmail.com
}

How to cite this paper: Diedhiou, A., Sow, L., Diouf, G.T.Y., Diop, M. and Diop, N.M. (2021) Experimental Geotechnical Characterization Campaign of the Matam Soil for Lithology: Application to the Study of Supports of the Balterdi Bridge. Open Journal of Civil Engineering, 11, 200-215.

https://doi.org/10.4236/ojce.2021.112013

Received: April 14, 2021

Accepted: June 13, 2021

Published: June 16, 2021

Copyright $\odot 2021$ by author(s) and Scientific Research Publishing Inc. This work is licensed under the Creative Commons Attribution International License (CC BY 4.0).

http://creativecommons.org/licenses/by/4.0/

\begin{abstract}
This paper presents a geotechnical study whose objective is to determine the lithology of the soil of Balterdi village (Matam, Senegal). A bridge-type structure with six supports is to be built on the studied site. The drilling program consisted of six core drillings (SC) each $30 \mathrm{~m}$ deep with sampling and six destructive drillings with pressuremeter tests (SP) every $1.5 \mathrm{~m}$ up to $30 \mathrm{~m}$ deep. A pair of core and pressuremeter tests was carried out under each support. From the results of the core drill holes and the geological model of the site, it can be seen that the lithology of the soil along the structure consists essentially of soft clay layers, becoming firm at depth over the first $18 \mathrm{~m}$ on average (with some incursions of sandy layers) resting on medium to compacted sand up to $30 \mathrm{~m}$. Brown clayey fill is also present between piers P3 and P5. The presence of a watercourse along the structure is noted. The foundations will therefore be carried out in the water. The results of the pressuremeter tests confirm the homogeneity of the soil over the whole area. Indeed, the values obtained are almost similar for all the tests. According to the limit pressures obtained, the clayey-sandy formations encountered along the structure are respectively soft to firm and moderately compact to compact. Their limit pressures are high enough to allow good bearing capacities.
\end{abstract}

\section{Keywords}

Geotechnical Behaviour, Cored Surveys, Pressuremeter Surveys, Lithology, Bridge Supports 


\section{Introduction}

In the geosciences group, geotechnical engineering is the technoscience dedicated to the practical study of the earth's subsurface on which our direct action is possible for its development and/or exploitation, Building and Public Works operations, groundwater management and natural risk prevention. It is therefore an essential discipline for all civil engineering structure designs. Concretely speaking, this science studies the feasibility of construction projects by looking for possible mechanical constraints on the site where the work is to be carried out. The geotechnical study proves to be very complex and consists in identifying on a given site the risks of natural phenomena or those, which may be induced by the works in order to draw the necessary conclusions concerning the project to be carried out and to guard against adequate solutions to avoid disastrous consequences. Study of the mechanical behaviour of materials used in public works in general has been of interest to the scientific community for a very long time. The case of materials studied in geotechnical engineering is also a branch of public works that attract a lot of interest. In recent decades, soil has been increasingly studied in order to better understand its behaviour [1]-[32]. A geotechnical study is based on the following important principles:

- defining if necessary a specific geotechnical investigation programme, carrying it out and exploiting the results;

- detailed study of the geotechnical works: in particular the establishment of a geotechnical hypothesis note on the basis of the available data;

- definition and dimensioning (supporting calculations) of the geotechnical structures, methods and conditions of execution (general phasing, monitoring, monitoring and checks to be carried out, threshold values, possible additional construction measures);

- drawing up the geotechnical execution file for the geotechnical works.

As with any geotechnical experimental campaign, it enables the residual geotechnical risks to be reduced by the timely implementation of corrective adaptation or optimization measures. The aim of the experimental campaign is the geotechnical study of soil in the village of Balterdi (Matam region, Senegal). This soil study is intended to prepare the construction of civil engineering works to be carried out on the site. For this study, the main objective is to determine the geotechnical characteristics of the soil at the level of the various supports of a bridge-type structure. The work presented in this article defines the lithology of the soil under each support and the mechanical and physical characteristics of the different soil layers encountered during the soundings carried out. A suitable foundation method is proposed in the next paper based on the results presented here.

\section{Geographical and Geological Overview of the Study Area}

The study area is located in the Matam region, which is one of the 14 administrative regions of Senegal. It is located in the northeast of the country and is bordered by the Saint-Louis region to the north, the Louga region to the west, the 
Kaffrine region to the south-west and the Tambacounda region to the south. To the East, it borders Mauritania. Matam is referenced by the geodetic coordinates N015 $06^{\prime} 18^{\prime \prime}$ and W13 $38^{\prime} 30^{\prime \prime}$. It is a zone with a Sahelian climate.

The geology of the Matam region can only be understood in the overall context of the Senegalese sedimentary basin, which is a segment of the Senegalese-Mauritanian-Guinean basin of Meso-Cenozoic age. According to the explanatory note of the geological map of Senegal at 1/500,000, north-western, north-eastern and south-western sheets, the area is covered by terrigenous formations of the Lower to Middle Eocene. These terrigenous deposits belong to the Gorgol and Matam formations, mainly composed of yellow to reddish ochre clayey sandstones with clayey beds. Figure 1 illustrates geographical location of Matam region.

\section{Study Methodology}

The drilling program consisted of six (06) core drillings (SC) each $30 \mathrm{~m}$ deep with sampling and six (06) destructive drillings with pressuremeter tests (SP) every $1.5 \mathrm{~m}$ up to $30 \mathrm{~m}$ deep. A pair of core and pressuremeter tests was carried out under each support of the planned structure. The following documents were used to carry out the study: geotechnical studies NF P94-500, core borehole NF EN ISO 22475-1, Menard pressure gauge NF EN ISO 22476-4, soil classification according to the road earthworks guide NF P11-300. Voluntary standards are 90\% of European or international origin. They can be recognised by their prefix: ISO for standards drawn up under the aegis of the International Organisation for Standardisation (where AFNOR represents France), EN for those of the European Committee for Standardisation (CEN).

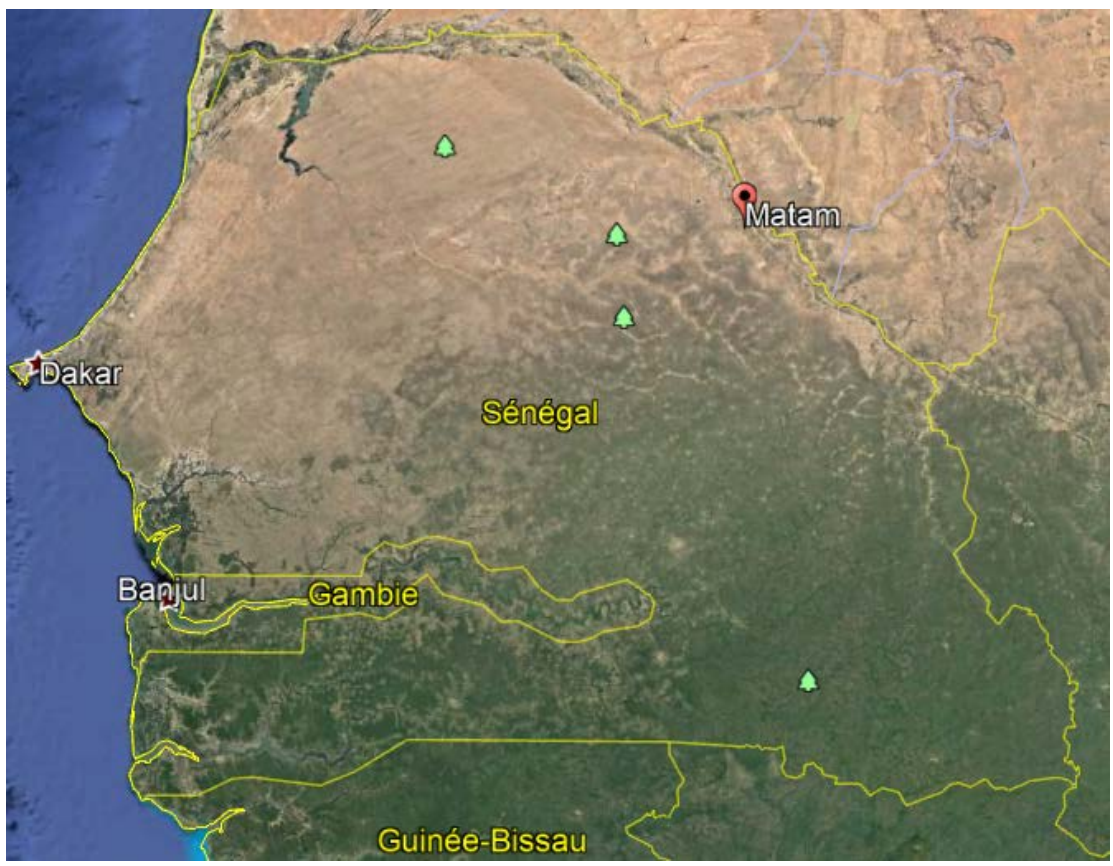

Figure 1. Geographical location of Matam, Senegal. 


\section{Results of Geotechnical Investigations}

\subsection{Coordinates and Location of Survey Points}

The surveys were implemented in accordance with the right of support of the work to be carried out at the rate of one survey per support. Their contact details are listed in Table 1. Figure 2 and Figure 3 illustrate the location of the various sounding points along the structure based on a projection of the coordinates on Google Earth Pro 2020.

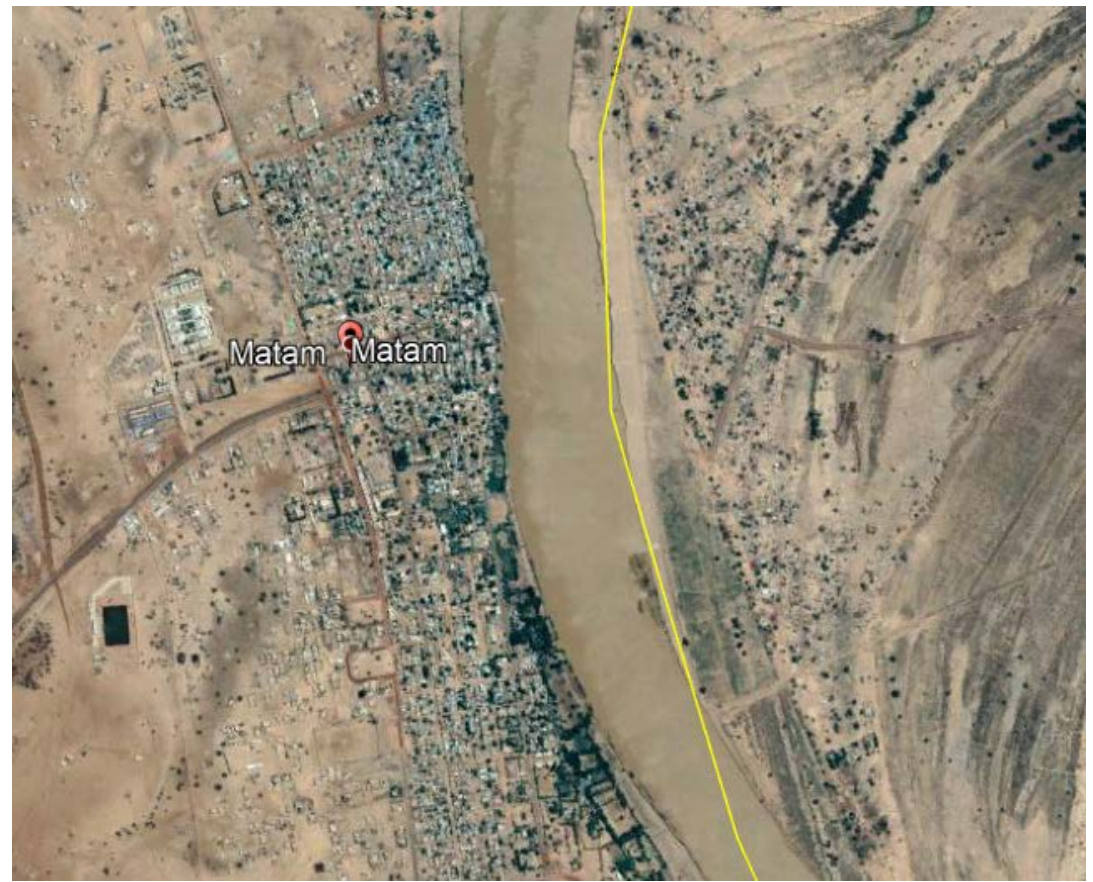

Figure 2. Geographical location of Balterdi village.

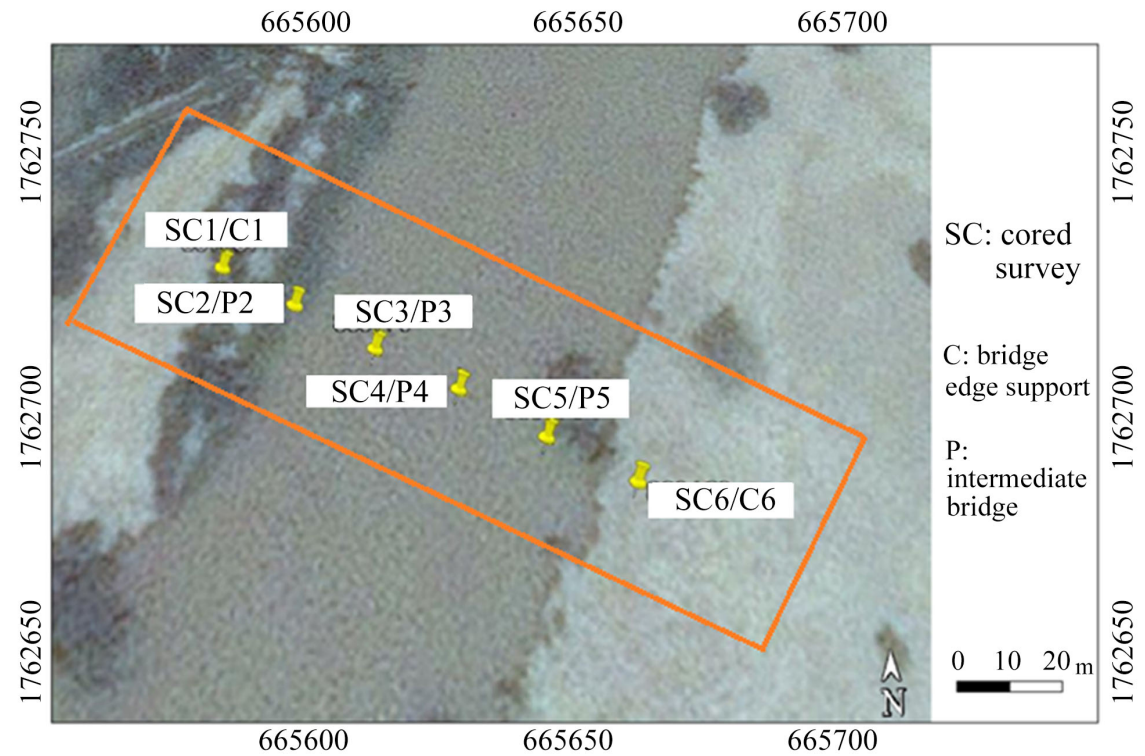

Figure 3. Layout of boreholes along the length of the structure. 
Table 1. Coordinates of the survey points.

\begin{tabular}{cccc}
\hline Bridge supports & Survey points & $\mathrm{X}$ & $\mathrm{Y}$ \\
\hline C1 & SC1/C1 & $665,579.389$ & $1,762,722.864$ \\
P2 & SC2/P2 & $665,594.985$ & $1,762,714.494$ \\
P3 & SC3/P3 & $665,610.845$ & $1,762,705.981$ \\
P4 & SC4/P4 & $665,626.704$ & $1,762,697.468$ \\
P5 & SC5/P5 & $665,642.564$ & $1,762,688.955$ \\
C6 & SC6/C6 & $665,658.160$ & $1,762,680.584$ \\
\hline
\end{tabular}

C: means edge support of a bridge. P: means intermediate bridge support.

\subsection{Cored Survey (SC)}

The core borehole allows the soil to be brought up to its natural state without any alteration. Depending on the tools used (stationary plunger, double, triple, thin-walled corer, etc.), coring allows samples to be taken which are then packaged and sent to our laboratories for identification and mechanical measurement. Drilling requires the use of a drilling fluid: water, drilling mud, foam, etc. At the end of the campaign, each borehole is the subject of a results section that includes the lithology defined from the core box survey by a geologist according to depth, the level of any water inflows at the beginning, during and at the end of drilling, the types of tools used and the techniques employed (casing, drilling mud, etc.), and any drilling anomalies encountered (loss of injection, void, etc.). The drilling diameter varies from 63 to $250 \mathrm{~mm}$ depending on the laboratory tests to be carried out or equipment to be used. This drilling enables a precise cut to be made to the centimetre. This drilling takes longer than other types of drilling. The images in Figure 4 show the tests. The image of Figure 5 shows the samples obtained with the core samples.

In the present work, six (06) core drill holes down to the shoreline $-30 \mathrm{~m}$ from the top of the river were carried out on site. The sounding machines were installed at the various points using a cofferdam that was set up. The boreholes were drilled using the core drilling method with mud injection. The diameter of the core drills used for this study was $101 \mathrm{~mm}$ and length $1.90 \mathrm{~m}$. The lithological sections obtained give the information in Table 2.

Based on the results of the core drillings, a longitudinal section was made to illustrate the lithology along the length of the structure (Figure 6).

From the results of the core drill holes and the geological model of the site, it can be seen that the lithology of the soil along the structure consists essentially of soft clay layers, becoming firm at depth over the first $18 \mathrm{~m}$ on average (with some incursions of sandy layers) resting on medium to compacted sand up to $30 \mathrm{~m}$. Brown clayey fill is also present between piers P3 and P5. The presence of a watercourse along the structure is noted. The foundations will therefore be carried out in the water. 


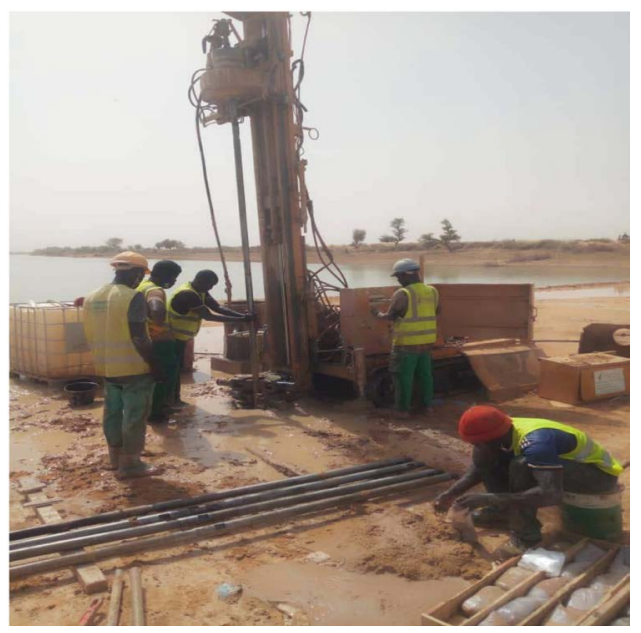

Figure 4. Images of cored surveys.

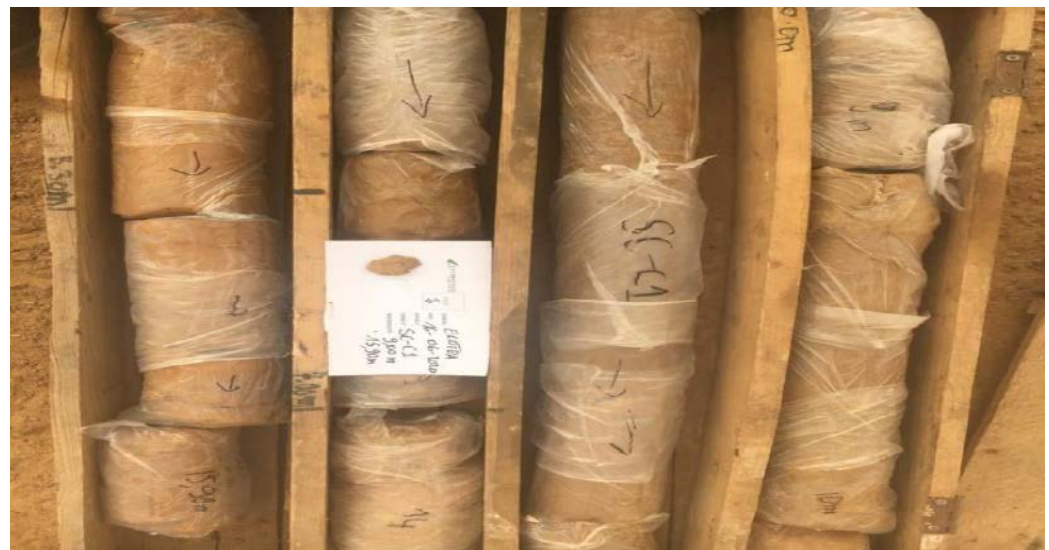

Figure 5. Images of cored surveys.
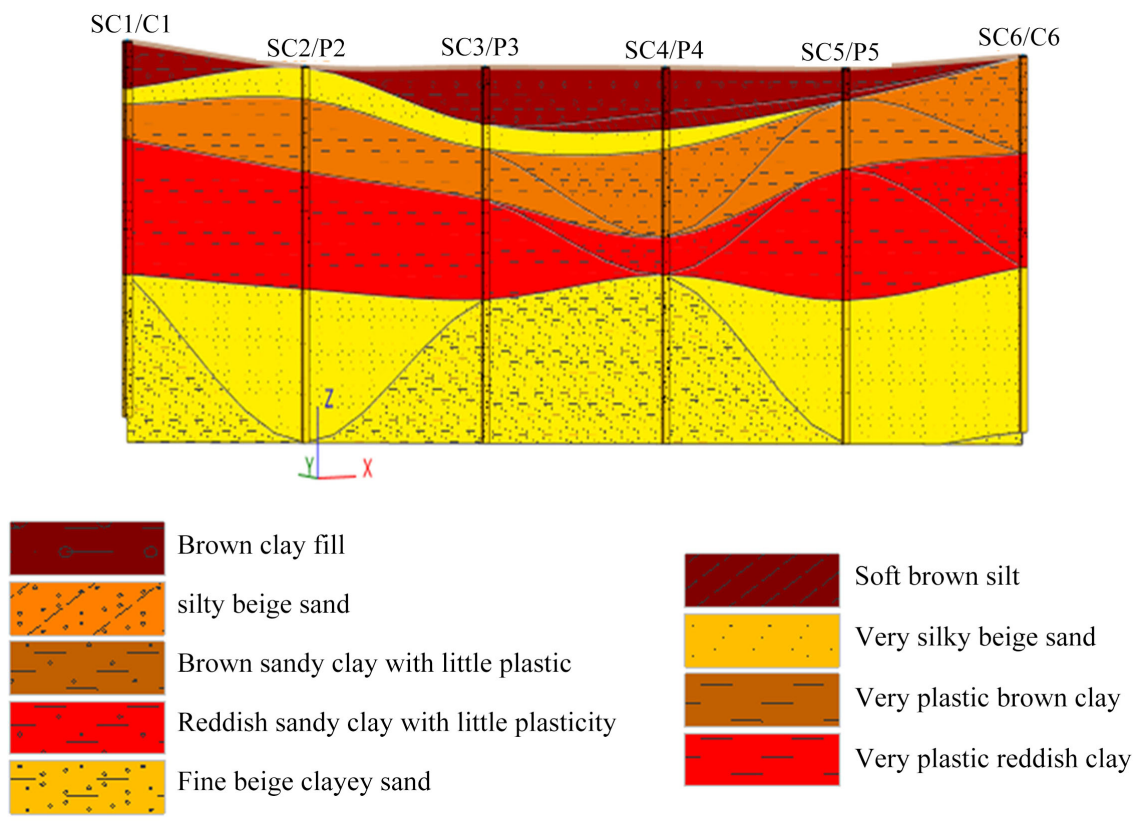

Figure 6. Soil lithology along the length of the structure. 
Table 2. Lithology of the soil studied.

\begin{tabular}{|c|c|c|}
\hline Bridge supports & Layer depth $(\mathrm{m})$ & Nature \\
\hline \multirow{5}{*}{$\mathrm{C} 1$} & $0-3.70$ & firm brown clay with little plastic \\
\hline & $3.70-6.20$ & loose beige sand very silty \\
\hline & $6.20-9.00$ & firm brown clay, very plastic \\
\hline & $9.00-19.80$ & firm reddish clay, very plastic \\
\hline & $19.80-30$ & fine beige medium compact sand \\
\hline \multirow{5}{*}{$\mathrm{P} 2$} & $0-2.50$ & soft brown clay very plastic \\
\hline & $2.50-5.50$ & loose beige silty sand \\
\hline & $5.50-8.30$ & firm brown clay, very plastic \\
\hline & $8.30-18.70$ & very firm reddish clay very plastic \\
\hline & $18.70-30$ & beige sand very silty medium compact to compact \\
\hline \multirow{5}{*}{ P3 } & $0-4.50$ & brown clay fill \\
\hline & $4.50-6.50$ & loose beige sand very silty \\
\hline & $6.50-10.50$ & firm brown clay, very plastic \\
\hline & $10.50-18.40$ & firm reddish clay, very plastic \\
\hline & $18.40-30$ & fine beige medium compact sand \\
\hline \multirow{6}{*}{$\mathrm{P} 4$} & $0-3.50$ & brown clay fill \\
\hline & $3.50-4.90$ & soft brown silt \\
\hline & $4.90-6.50$ & beige sand very silty medium compact \\
\hline & $6.50-13.5$ & firm brown clay with little plastic \\
\hline & $13.5-16.5$ & firm reddish clay with little plasticity \\
\hline & $16.5-30$ & fine beige medium compact sand \\
\hline \multirow{5}{*}{ P5 } & $0-1.90$ & brown clay fill \\
\hline & $1.90-2.50$ & firm brown silt \\
\hline & $2.50-8.00$ & soft brown clay very plastic \\
\hline & $8.00-18.50$ & firm reddish clay, very plastic \\
\hline & $18.5-30$ & beige sand very silty medium compact to compact \\
\hline \multirow{3}{*}{$\mathrm{C} 6$} & $0-7.70$ & firm brown clay with little plastic \\
\hline & $7.70-16.8$ & firm reddish clay with little plasticity \\
\hline & $16.8-30$ & beige sand very silty medium compact \\
\hline
\end{tabular}

\subsection{Pressuremeter Surveys (SP)}

The pressuremeter test is an in situ geotechnical test, the principle of which is to measure soil deformation and breakage by means of a nitrogen-inflated probe. 
This test is carried out in a preliminary destructive borehole with a maximum diameter of $64 \mathrm{~mm}$. The parameters measured are the water pressure applied to the measuring cell of the pressure probe, the air pressure applied to the guard cells of the probe and the volume of water injected into the probe. The spacing of the tests varies from $0.8 \mathrm{~m}$ to $1.5 \mathrm{~m}$ within the same borehole depending on the type of soil encountered and the precision required. They are the subject of a graphical restitution, which groups together the destructive sounding section, and the mechanical values of the tests as a function of depth. Each test is stopped when the maximum pressure reaches five MPa, or when the volume of the probe reaches $600 \mathrm{~cm}^{3}$ for a standard probe or $450 \mathrm{~cm}^{3}$ for a pile probe. The images in Figure 7 show the tests. In this work, the surveys were carried out in accordance with standard NF EN ISO 22476-4. The destructive drilling was carried out using a $63 \mathrm{~mm}$ diameter toothed tricone. This allows an intact ground without any particular modification. In addition, due to the clayey nature of the soil, the toothed tricone is a disaggregating tool that allows easy crossing of the ground. The pressuremeter readings were taken in $1.50 \mathrm{~m}$ increments. This test consists of a static loading of the soil in place. The method consists of introducing inside a well-calibrated borehole a radially expandable cylindrical probe connected to a pressure-volume controller, which allows a quantity of liquid to be injected under a given pressure using compressed gas between the metal core and the deforming membrane.

By applying increasing pressure, a cylindrical stress field is exerted on the borehole walls. The change in the liquid level in the pressure-volume controller therefore measures the corresponding deformation field as a function of pressure and time. The results of these tests are used to produce diagrams showing the deformation modulus $\left(E_{M}\right)$ of the borehole, the limiting pressures $\left(P_{l}\right)$ as a function of depth. The results obtained are recorded in Tables 3-8. The following is also mentioned in these tables:

$\checkmark P_{I}^{\star}$ : net limit pressure $\left.=P_{I}-\sigma_{h s}\right)$ which characterises the breaking strength of the soil.

$\checkmark$ the creep pressure $\left(P_{f}\right)$ which defines the limit between the pseudo-elastic behaviour and the plastic state the horizontal stress $\sigma_{h s}$

For the six Pressuremeter soundings, statistical processing was carried out based on all the limit pressure values and Menard modules obtained in order to better assess the evolution and variation of the mechanical characteristics of the soil along the site. The results obtained are recorded in Table 9.

The results of the Pressuremeter tests confirm the homogeneity of the soil over the whole area. Indeed, the values obtained are almost similar for all the tests. According to the limit pressures obtained, the clayey-sandy formations encountered along the structure are respectively soft to firm and moderately compact to compact. Their limit pressures are high enough to allow good bearing capacities. Figure 8 below shows the evolution of the limit pressures as a function of depth. 


\section{Discussions}

The various results from the core drilling operations have revealed three distinct soil horizons:

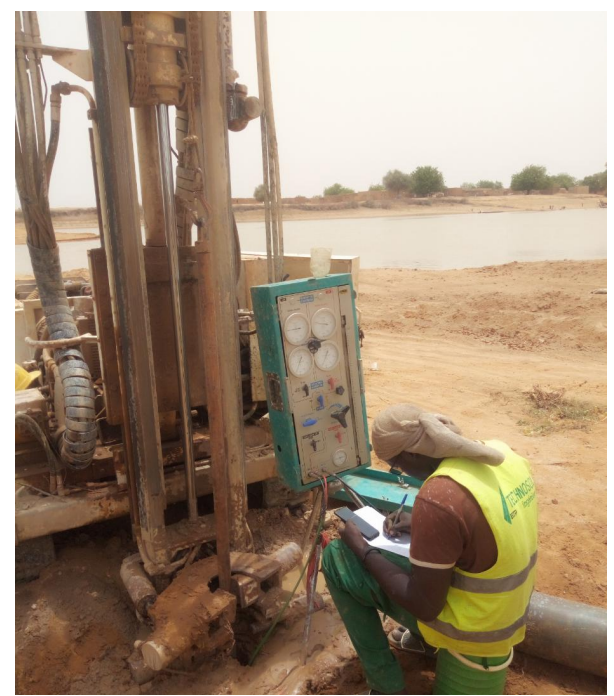

Figure 7. Images of Pressuremeter surveys.

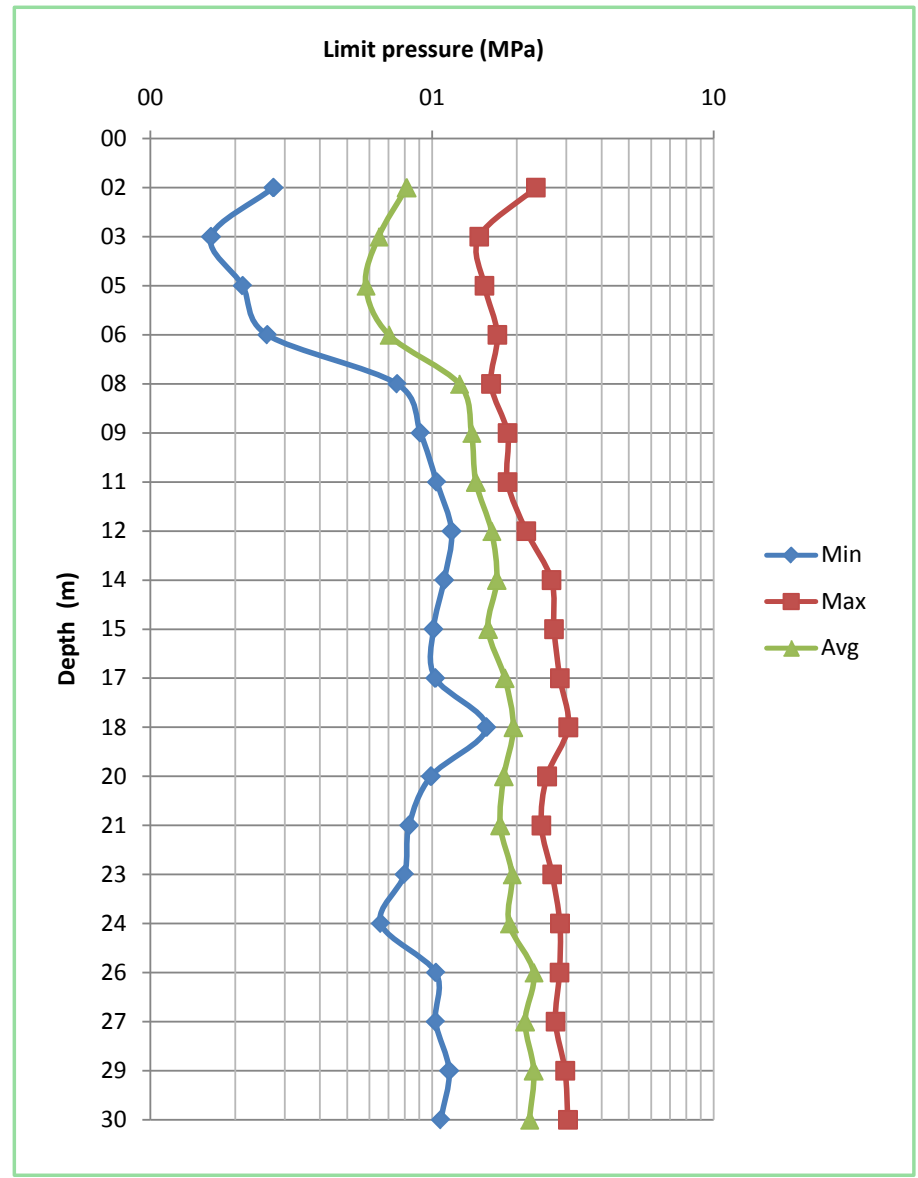

Figure 8. Limit pressure variation curves (minimum-maximum-average). 
Table 3. Summary of the Pressuremeter characteristics obtained with SP1/C1.

\begin{tabular}{ccccccc}
\hline Depth $(\mathrm{m})$ & $P_{f}(\mathrm{MPa})$ & $P_{I}(\mathrm{MPa})$ & $\sigma_{h s}(\mathrm{MPa})$ & $P_{I}^{*}(\mathrm{MPa})$ & $E_{M}(\mathrm{MPa})$ & $E_{M} / P_{I}$ \\
\hline 1.50 & 0.57 & 0.83 & 0.013 & 0.81 & 14.3 & 17.6 \\
3.00 & 0.59 & 0.84 & 0.027 & 0.81 & 14.3 & 17.6 \\
4.50 & 0.19 & 0.35 & 0.040 & 0.31 & 4.4 & 14.0 \\
6.00 & 0.15 & 0.42 & 0.054 & 0.37 & 5.2 & 14.3 \\
7.50 & 0.99 & 1.56 & 0.067 & 1.49 & 14.1 & 9.4 \\
9.00 & 1.31 & 1.60 & 0.081 & 1.52 & 19.6 & 12.9 \\
10.50 & 1.46 & 1.86 & 0.094 & 1.76 & 20.1 & 11.4 \\
12.00 & 1.42 & 1.67 & 0.108 & 1.56 & 14.6 & 9.4 \\
13.50 & 1.26 & 2.06 & 0.121 & 1.94 & 22.7 & 11.7 \\
15.00 & 0.66 & 1.51 & 0.135 & 1.37 & 15.3 & 11.1 \\
16.50 & 1.37 & 1.87 & 0.148 & 1.72 & 13.7 & 8.0 \\
18.00 & 0.82 & 1.74 & 0.162 & 1.58 & 12.8 & 8.1 \\
19.50 & 0.82 & 1.85 & 0.175 & 1.68 & 18.7 & 11.2 \\
21.00 & 1.42 & 2.00 & 0.189 & 1.81 & 16.0 & 8.8 \\
22.50 & 1.57 & 1.94 & 0.202 & 1.74 & 13.3 & 7.6 \\
24.00 & 1.19 & 2.46 & 0.216 & 2.24 & 14.4 & 6.4 \\
25.50 & 1.87 & 2.81 & 0.229 & 2.58 & 22.7 & 8.8 \\
27.00 & 1.90 & 2.74 & 0.243 & 2.50 & 23.6 & 9.4 \\
28.50 & 1.67 & 2.97 & 0.256 & 2.71 & 24.9 & 9.2 \\
30.00 & 1.71 & 3.04 & 0.270 & 2.77 & 24.6 & 8.9 \\
\hline
\end{tabular}

Table 4. Summary of the Pressuremeter characteristics obtained with SP2/P2.

\begin{tabular}{ccccccc}
\hline Depth $(\mathrm{m})$ & $P_{f}(\mathrm{MPa})$ & $P_{I}(\mathrm{MPa})$ & $\sigma_{h s}(\mathrm{MPa})$ & $P_{I}^{*}(\mathrm{MPa})$ & $E_{M}(\mathrm{MPa})$ & $E_{M} / P_{I}$ \\
\hline 1.50 & 0.09 & 0.27 & 0.013 & 0.26 & 4.1 & 15.6 \\
3.00 & 0.07 & 0.16 & 0.027 & 0.14 & 3.0 & 21.7 \\
4.50 & 0.24 & 0.32 & 0.040 & 0.28 & 6.2 & 21.9 \\
6.00 & 0.30 & 0.62 & 0.054 & 0.57 & 5.5 & 9.8 \\
7.50 & 1.03 & 1.36 & 0.067 & 1.29 & 18.1 & 14.0 \\
9.00 & 1.65 & 1.85 & 0.081 & 1.77 & 27.2 & 15.3 \\
10.50 & 0.91 & 1.75 & 0.094 & 1.65 & 18.4 & 11.2 \\
12.00 & 1.05 & 2.16 & 0.108 & 2.05 & 38.0 & 18.5 \\
13.50 & 1.46 & 2.66 & 0.121 & 2.53 & 20.2 & 8.0 \\
15.00 & 1.05 & 2.71 & 0.135 & 2.58 & 34.3 & 13.3 \\
16.50 & 1.78 & 2.85 & 0.148 & 2.70 & 25.3 & 9.4 \\
18.00 & 1.54 & 3.05 & 0.162 & 2.89 & 25.4 & 8.8 \\
19.50 & 2.29 & 2.56 & 0.175 & 2.39 & 26.3 & 11.0 \\
21.00 & 1.29 & 2.08 & 0.189 & 1.90 & 21.8 & 11.5 \\
22.50 & 1.61 & 2.57 & 0.202 & 2.36 & 22.2 & 9.4 \\
24.00 & 1.14 & 1.93 & 0.216 & 1.71 & 27.8 & 16.2 \\
25.50 & 1.36 & 2.83 & 0.229 & 2.60 & 31.8 & 12.2 \\
27.00 & 1.37 & 2.25 & 0.243 & 2.01 & 14.5 & 7.2 \\
28.50 & 1.41 & 2.53 & 0.256 & 2.27 & 23.6 & 10.4 \\
30.00 & 1.91 & 2.68 & 0.270 & 2.41 & 28.9 & 12.0 \\
\hline
\end{tabular}


Table 5. Summary of the Pressuremeter characteristics obtained with SP3/P3.

\begin{tabular}{ccccccc}
\hline Depth $(\mathrm{m})$ & $P_{f}(\mathrm{MPa})$ & $P_{I}(\mathrm{MPa})$ & $\sigma_{h s}(\mathrm{MPa})$ & $P_{1}^{*}(\mathrm{MPa})$ & $E_{M}(\mathrm{MPa})$ & $E_{M} / P_{I}$ \\
\hline 1.50 & 0.17 & 0.32 & 0.013 & 0.30 & 1.2 & 3.8 \\
3.00 & 0.09 & 0.17 & 0.027 & 0.14 & 1.5 & 10.4 \\
4.50 & 0.13 & 0.21 & 0.040 & 0.17 & 1.0 & 5.6 \\
6.00 & 0.12 & 0.26 & 0.054 & 0.21 & 1.3 & 6.1 \\
7.50 & 0.39 & 0.75 & 0.067 & 0.68 & 3.8 & 5.5 \\
9.00 & 0.19 & 0.91 & 0.081 & 0.83 & 15.9 & 19.2 \\
10.50 & 0.76 & 1.04 & 0.094 & 0.94 & 10.2 & 10.8 \\
12.00 & 1.18 & 1.71 & 0.108 & 1.60 & 19.4 & 12.1 \\
13.50 & 1.06 & 1.68 & 0.121 & 1.56 & 16.3 & 10.5 \\
15.00 & 1.09 & 1.30 & 0.135 & 1.16 & 14.0 & 12.0 \\
16.50 & 1.24 & 1.58 & 0.148 & 1.43 & 19.8 & 13.8 \\
18.00 & 1.11 & 1.78 & 0.162 & 1.62 & 15.8 & 9.7 \\
19.50 & 1.12 & 1.49 & 0.175 & 1.31 & 13.4 & 10.2 \\
21.00 & 0.97 & 1.30 & 0.189 & 1.11 & 12.4 & 11.2 \\
22.50 & 1.29 & 1.75 & 0.202 & 1.54 & 14.1 & 9.1 \\
24.00 & 0.74 & 1.53 & 0.216 & 1.31 & 11.2 & 8.5 \\
25.50 & 1.87 & 2.65 & 0.229 & 2.42 & 36.8 & 15.2 \\
27.00 & 1.74 & 2.44 & 0.243 & 2.20 & 33.2 & 15.1 \\
28.50 & 1.77 & 2.82 & 0.256 & 2.56 & 30.7 & 12.0 \\
30.00 & 1.99 & 2.32 & 0.270 & 2.05 & 37.5 & 18.3 \\
\hline
\end{tabular}

Table 6. Summary of the Pressuremeter characteristics obtained with SP4/P4.

\begin{tabular}{ccccccc}
\hline Depth $(\mathrm{m})$ & $P_{f}(\mathrm{MPa})$ & $P_{I}(\mathrm{MPa})$ & $\sigma_{h s}(\mathrm{MPa})$ & $P_{I}^{\star}(\mathrm{MPa})$ & $E_{M}(\mathrm{MPa})$ & $E_{M} / P_{I}$ \\
\hline 1.50 & 0.20 & 0.33 & 0.013 & 0.31 & 6.7 & 21.5 \\
3.00 & 0.22 & 0.34 & 0.027 & 0.31 & 6.6 & 21.2 \\
4.50 & 0.36 & 0.66 & 0.040 & 0.62 & 5.1 & 8.2 \\
6.00 & 0.37 & 0.68 & 0.054 & 0.62 & 5.2 & 8.3 \\
7.50 & 0.63 & 1.07 & 0.067 & 1.00 & 9.8 & 9.7 \\
9.00 & 0.70 & 1.26 & 0.081 & 1.18 & 8.0 & 6.8 \\
10.50 & 0.49 & 1.22 & 0.094 & 1.12 & 11.7 & 10.4 \\
12.00 & 0.69 & 1.17 & 0.108 & 1.07 & 9.4 & 8.8 \\
13.50 & 1.06 & 1.29 & 0.121 & 1.17 & 13.5 & 11.6 \\
15.00 & 1.07 & 1.43 & 0.135 & 1.29 & 12.7 & 9.8 \\
16.50 & 1.37 & 1.59 & 0.148 & 1.44 & 13.1 & 9.1 \\
18.00 & 1.26 & 1.56 & 0.162 & 1.40 & 14.3 & 10.2 \\
19.50 & 1.12 & 1.80 & 0.175 & 1.62 & 15.4 & 9.5 \\
21.00 & 1.42 & 1.82 & 0.189 & 1.64 & 15.8 & 9.7 \\
22.50 & 0.87 & 1.81 & 0.202 & 1.61 & 13.9 & 8.7 \\
24.00 & 0.92 & 1.84 & 0.216 & 1.62 & 12.9 & 7.9 \\
25.50 & 1.19 & 1.92 & 0.229 & 1.69 & 17.2 & 10.2 \\
27.00 & 1.73 & 1.81 & 0.243 & 1.57 & 22.3 & 14.2 \\
28.50 & 1.63 & 1.98 & 0.256 & 1.72 & 14.0 & 8.1 \\
30.00 & 1.22 & 1.83 & 0.270 & 1.56 & 17.6 & 11.3 \\
\hline
\end{tabular}


Table 7. Summary of the Pressuremeter characteristics obtained with SP5/P5.

\begin{tabular}{ccccccc}
\hline Depth $(\mathrm{m})$ & $P_{f}(\mathrm{MPa})$ & $P_{I}(\mathrm{MPa})$ & $\sigma_{h s}(\mathrm{MPa})$ & $P_{I}^{*}(\mathrm{MPa})$ & $E_{M}(\mathrm{MPa})$ & $E_{M} / P_{I}$ \\
\hline 1.50 & 0.47 & 0.80 & 0.013 & 0.79 & 8.6 & 11.0 \\
3.00 & 0.70 & 0.89 & 0.027 & 0.86 & 9.8 & 11.4 \\
4.50 & 0.18 & 0.40 & 0.040 & 0.36 & 3.1 & 8.7 \\
6.00 & 0.40 & 0.53 & 0.054 & 0.48 & 8.0 & 16.7 \\
7.50 & 0.85 & 1.14 & 0.067 & 1.07 & 17.1 & 16.0 \\
9.00 & 0.65 & 1.20 & 0.081 & 1.12 & 14.3 & 12.8 \\
10.50 & 0.63 & 1.29 & 0.094 & 1.20 & 12.1 & 10.1 \\
12.00 & 0.50 & 1.65 & 0.108 & 1.54 & 17.4 & 11.3 \\
13.50 & 0.32 & 1.10 & 0.121 & 0.98 & 12.8 & 13.0 \\
15.00 & 0.69 & 1.01 & 0.135 & 0.88 & 9.7 & 11.0 \\
16.50 & 0.71 & 1.03 & 0.148 & 0.88 & 9.7 & 11.0 \\
18.00 & 0.56 & 1.71 & 0.162 & 1.54 & 17.4 & 11.2 \\
19.50 & 1.02 & 2.10 & 0.175 & 1.92 & 13.0 & 6.8 \\
21.00 & 1.34 & 2.45 & 0.189 & 2.26 & 27.6 & 12.3 \\
22.50 & 1.60 & 2.67 & 0.202 & 2.47 & 23.1 & 9.4 \\
24.00 & 1.86 & 2.85 & 0.216 & 2.63 & 32.8 & 12.5 \\
25.50 & 1.66 & 2.52 & 0.229 & 2.29 & 23.5 & 10.2 \\
27.00 & 1.66 & 2.58 & 0.243 & 2.33 & 23.0 & 9.9 \\
28.50 & 1.65 & 2.35 & 0.256 & 2.09 & 18.8 & 9.0 \\
30.00 & 1.67 & 2.36 & 0.270 & 2.09 & 18.8 & 9.0 \\
\hline
\end{tabular}

Table 8. Summary of the Pressuremeter characteristics obtained with SP6/C6.

\begin{tabular}{ccccccc}
\hline Depth $(\mathrm{m})$ & $P_{f}(\mathrm{MPa})$ & $P_{I}(\mathrm{MPa})$ & $\sigma_{h s}(\mathrm{MPa})$ & $P_{I}^{*}(\mathrm{MPa})$ & $E_{M}(\mathrm{MPa})$ & $E_{M} / P_{I}$ \\
\hline 1.50 & 1.43 & 2.34 & 0.013 & 2.32 & 18.2 & 7.8 \\
3.00 & 0.95 & 1.47 & 0.027 & 1.44 & 14.5 & 10.0 \\
4.50 & 0.69 & 1.54 & 0.040 & 1.49 & 14.5 & 9.7 \\
6.00 & 0.98 & 1.71 & 0.054 & 1.65 & 17.0 & 10.3 \\
7.50 & 1.26 & 1.62 & 0.067 & 1.55 & 12.4 & 8.0 \\
9.00 & 1.16 & 1.47 & 0.081 & 1.39 & 16.8 & 12.1 \\
10.50 & 0.60 & 1.44 & 0.094 & 1.35 & 21.5 & 16.0 \\
12.00 & 1.15 & 1.40 & 0.108 & 1.29 & 10.8 & 8.4 \\
13.50 & 0.53 & 1.40 & 0.121 & 1.27 & 10.1 & 8.0 \\
15.00 & 1.05 & 1.53 & 0.135 & 1.40 & 12.7 & 9.1 \\
16.50 & 1.23 & 1.97 & 0.148 & 1.82 & 14.5 & 8.0 \\
18.00 & 0.68 & 1.82 & 0.162 & 1.66 & 16.0 & 9.6 \\
19.50 & 0.49 & 0.99 & 0.175 & 0.82 & 6.4 & 7.9 \\
21.00 & 0.74 & 0.83 & 0.189 & 0.64 & 9.2 & 14.4 \\
22.50 & 0.56 & 0.80 & 0.202 & 0.60 & 6.7 & 11.3 \\
24.00 & 0.50 & 0.66 & 0.216 & 0.44 & 9.1 & 20.7 \\
25.50 & 0.58 & 1.03 & 0.229 & 0.80 & 6.7 & 8.4 \\
27.00 & 0.66 & 1.03 & 0.243 & 0.79 & 8.2 & 10.5 \\
28.50 & 0.85 & 1.15 & 0.256 & 0.89 & 8.9 & 9.9 \\
30.00 & 0.68 & 1.07 & 0.270 & 0.80 & 7.4 & 9.2 \\
\hline
\end{tabular}


Table 9. Mean values of limit pressures and Menard modules.

\begin{tabular}{ccccccc}
\hline \multirow{2}{*}{ Depth $(\mathrm{m})$} & \multicolumn{3}{c}{ Limit pressures } & \multicolumn{3}{c}{ Menard modules } \\
\cline { 2 - 6 } & Min (MPa) & Max (MPa) & Avg (MPa) & Min (MPa) & Max (MPa) & Avg (MPa) \\
\hline 1.50 & 0.27 & 2.34 & 0.81 & 1.2 & 18.2 & 8.8 \\
3.00 & 0.16 & 1.47 & 0.65 & 1.5 & 14.5 & 8.3 \\
4.50 & 0.21 & 1.54 & 0.58 & 1.0 & 14.5 & 5.7 \\
6.00 & 0.26 & 1.71 & 0.70 & 1.3 & 17.0 & 7.0 \\
7.50 & 0.75 & 1.62 & 1.25 & 3.8 & 18.1 & 1.5 \\
9.00 & 0.91 & 1.85 & 1.38 & 8.0 & 27.2 & 17.0 \\
10.5 & 1.04 & 1.86 & 1.43 & 10.2 & 21.5 & 15.7 \\
12.0 & 1.17 & 2.16 & 1.63 & 9.4 & 38.0 & 18.3 \\
13.5 & 1.10 & 2.66 & 1.70 & 10.1 & 22.7 & 16.0 \\
15.0 & 1.01 & 2.71 & 1.58 & 9.7 & 34.3 & 16.4 \\
16.5 & 1.03 & 2.85 & 1.81 & 9.7 & 25.3 & 16.0 \\
18.0 & 1.56 & 3.05 & 1.94 & 12.8 & 25.4 & 16.9 \\
19.5 & 0.99 & 2.56 & 1.80 & 6.4 & 26.3 & 15.5 \\
21.0 & 0.83 & 2.45 & 1.75 & 9.2 & 27.6 & 17.1 \\
22.5 & 0.80 & 2.67 & 1.92 & 6.7 & 23.1 & 15.6 \\
24.0 & 0.66 & 2.85 & 1.88 & 9.1 & 32.8 & 18.0 \\
25.5 & 1.03 & 2.83 & 2.29 & 6.7 & 36.8 & 23.1 \\
27.0 & 1.03 & 2.74 & 2.14 & 8.2 & 33.2 & 20.8 \\
28.5 & 1.15 & 2.97 & 2.30 & 8.9 & 30.7 & 20.1 \\
30.0 & 1.07 & 3.04 & 2.22 & 7.4 & 37.5 & 22.5 \\
\hline
\end{tabular}

- Brown to reddish clay with little plasticity belonging to class A2 (Fine soils) according to the NF P11-300 standard. The synthesis of the pressure measurement results found indicates that these soils have a firm consistency.

- Brown to reddish brown clay with high plasticity belong to class A3 (Fine soils) according to NF P11-300 standard. The synthesis of the Pressuremeter results found indicates that these soils have a soft to firm consistency.

- Silty beige to very silty sand belonging to class B (sandy and gravelly soil with fines) according to the NF P11-300 standard. The synthesis of the Pressuremeter results shows that these formations are of loose to medium compact consistency.

\section{Conclusion and Perspectives}

This work allowed the geotechnical characterization and lithology of the soil of the village of Balterdi. The results are of paramount importance for the civil engineering works to be built on-site. In view of the nature of the planned works on the site under study, it would be useful if the samples taken from the cores could be tested and subjected to physical-mechanical analysis in the laboratory. The next stage of the work therefore consists of physical identification tests, mechanical identification tests, chemical analysis tests on soil and chemical analysis tests on groundwater. These last-mentioned works will be proposed in a later ar- 
ticle.

\section{Acknowledgements}

Authors address special thanks to Technosol Engineering staff.

\section{Conflicts of Interest}

The authors declare no conflicts of interest regarding the publication of this paper.

\section{References}

[1] Kansango, M.P., Kavula, N.E., Sow, L. and Lunda, H.J.M. (2019) Geotechnical Mapping by Deep Learning Artificial Neural Network Approach. European Scientific Journal, 15, 233-251.

[2] Kavula, N.E., Kansango, M.P., Sow, L., Bilez, N.B., Corneille, K.M. and Obed, T.K. (2020) Coupling Discriminating Statistical Analysis and Artificial Intelligence for Geotechnical Characterization of the Kampemba's Municipality Soils (Lubumbashi, DR Congo). Geomaterials, 10, 35-55. https://doi.org/10.4236/gm.2020.103003

[3] Sow, L. (2020) Study of the Behaviour of Senegalese Ballast Materials during Compaction with the C-Mould: Case of Bandia Limestone and Diack Basalt. Key Engineering Materials, 831, 81-86.

https://doi.org/10.4028/www.scientific.net/KEM.831.81

[4] Olsen, R.S. (1994) Normalization and Prediction of Geotechnical Properties Using the Cone Penetrometer Test (CPT). US Army Engineer Waterways Experiment Station, Vicksburg.

[5] Gupta, R., Rodrigo, S., Mitchell, J. and Jamiolkowski, M. (2001) Calibration Chamber Size Effects on Penetration Resistance in Sand. Journal of Geotechnical and Geoenvironmental Engineering, 127, 628. https://doi.org/10.1061/(ASCE)1090-0241(2001)127:7(628)

[6] Holden, J.C. (1971) Research on Performance of Soil Penetrometers. Internal Report, Country Roads Board of Victoria, Victoria.

[7] Ghionna, V.N. and Jamliolkowski, H. (1991) A Critical Appraisal of Calibration Chamber Testing of Sands. Proceedings of the 1 st International Symposium on Calibration Chamber Testing, Potsdam, 28-29 June 1991, 13-39.

[8] Salgado, R., Mitchel, J.K. and Jamiolkowski, M. (1998) Calibration Chamber Size Effects on Penetration Resistance in Sand. Journal of Geotechnical and Geoenvironmental Engineering, 124, 878-888. https://doi.org/10.1061/(ASCE)1090-0241(1998)124:9(878)

[9] Sow, L., Diouf, G.T.Y. and Diop, M. (submitted) Experimental Campaign for the Physical, Mechanical and Chemical Characterization of the Matam Soil: Application to the Study of Supports of the Balterdi Bridge. Innovative Infrastructure Solutions, Springer, Switzerland.

[10] Diedhiou, A., Sow, L. and Dione, A. (2020) Contribution to Comparative Study of Physical-Chemical Characteristics of Diack Basalt and Bandia Limestone for Use in Railway Engineering. Geomaterials, 10, 25-34. https://doi.org/10.4236/gm.2020.102002

[11] Fawaz, A., Farah, E. and Hagechehade, F. (2014) Study and Relation between the Pressuremeter and Elastic Moduli of Soil, National Geotechnical and Engineering 
Geology Days JNGG2014.

https://www.semanticscholar.org/paper/A-Study-of-the-Pressuremeter-Modulus-an d-Its-to-the-Fawaz-Hagechehade/c753f8e52bf301911e39f9e917474b584774a702

[12] Baguelin, F., Jézequel, J.F. and Shields, D.H. (1978) The Pressuremeter and Foundation Engineering, Series on Rock and Soil Méchanics. Trans Tech Publications, Clausthal.

[13] Biarez, J., Gambin, M., Gomes-Correia, A., Flavigny, E. and Branque, D. (1998) Using Pressuremeter to Obtain Parameters to Elastic-Plastic Models for Sands. Geotechnical Site Characterization, Roberton \& Mayne, Balkerna, Rotterdam.

[14] Gambin, M., Flavigny, E. and Boulon, M. (1996) The Pressuremeter Module: History and Modelling. 11 th Franco-Polish Colloquium on Soil and Applied Rock Mechanics, Gdansk, 53-60.

[15] Goh, K.H., Jeyatharan, K. and Wen, D. (2012) Understanding the Stiffness of Soils in Singapore from Pressuremeter Testing. Geotechnical Engineering Journal of the SEAGS \& AGSSEA, 43, No. 4.

[16] Cailletaud, G. and Pilvin, P. (1994) Identification and Inverse Problems Related to Material Behavior. In: Inverse Problems in Engineering Mechanics, Balkema, Rotterdam, 79-86.

[17] Cambou, B. and Bahar, R. (1993) Use of the Pressuremeter Test for the Identification of Intrinsic Parameters of the Behaviour of a Soil. Revue Francaise de Géotechnique, 63, 39-50. https://doi.org/10.1051/geotech/1993063039

[18] Dano, C., Hicher, P.-Y., Tailliez, S. and Varjabedian, M. (2002) Identification of the Behaviour Parameters of the Injected Soils by Inverse Analysis of Pressuremeter Tests. Revue Française de Génie Civil, 6, 631-660. https://doi.org/10.1080/12795119.2002.9692392

[19] Graham, J., Crooks, J.H. and Bell, A.L. (1983) Time Effects on the Stress Strain Behavior of Soft Natural Clays. Géotechnique, 33, 327-340.

https://doi.org/10.1680/geot.1983.33.3.327

[20] Gibson, R.E. and Anderson, W.F. (1961) In Situ Measurement of Soils Properties with the Pressuremeter. Civil Engineering and Public Works Review, 56, 615-618. https://doi.org/10.6013/jbrewsocjapan1915.56.618

[21] Hicher, P.Y. (1985) Mechanical Behaviour of Saturated Clays on Various Monotonous and Cyclic Load Paths. Application to Elastoplastic and Viscoplastic Modelling. PhD Thesis, Université Paris 6, Paris.

[22] Hicher, P.Y. and Michali, A. (1996) Identifying Soil Parameters by Means of Laboratory and in Situ Testing. Computers and Geotechnics, 19, 153-170. https://doi.org/10.1016/0266-352X(96)00040-7

[23] Hicher, P.Y. and Shao, J.F. (2002) Methods for Identifying Parameters in Models of Soil and Rock Behaviour 2: Incremental Laws, Viscoplasticity, Damage, Ed. Hermes, 203-230.

[24] Mestat, P. and Riou, Y. (2002) Modélisation des sols et des ouvrages avec le modèle Cam-Clay Modifié. HAL Archives, 6, 801-815.

https://hal.archives-ouvertes.fr/hal-01007070/document

[25] Monnet, J. and Khlif, J. (1994) Study of the Elasto-Plastic Equilibrium of a Powdered Soil around the Pressure Meter. Revue Francaise de Géotechnique, 67, 3-12.

[26] Monnet, J. (1995) Theoretical and Experimental Analysis of the Elastoplastic Equilibrium of a Coherent Soil around the Pressuremeter, the Pressuremeter and Its New Avenues. Balkema, Rotterdam, 193-200. 
[27] Rangeard, D. (2002) Identification of the Hydro-Mechanical Characteristics of a Clay by Inverse Analysis of Pressuremeter Tests. Ph.D. Thesis, Ecole Centrale de Nantes et Université de Nantes, Nantes.

[28] Rangeard, D., Hicher, P.Y. and Zentar, R. (2003) Determining Soil Permeability from Pressuremeter Tests. International Journal for Numerical and Analytical Methods in Geomechanics, 27, 1-24. https://doi.org/10.1002/nag.258

[29] Rangeard, D. and Hicher, P.Y. (2003) Interpretation of Pressiometric Tests I. Influence of Soil Permeability. Revue Française de Génie Civil, 8, No. 7. https://doi.org/10.3166/rfgc.8.793-817

[30] Sheahan, T.C., Ladd, C.C. and Germaine, J.T. (1994) Time-Dependent Triaxial Relaxation Behavior of a Resedimented Clay. Geotechnical Testing Journal, 17, 444-452. https://doi.org/10.1520/GTJ10305J

[31] Yu, H.S. and Houlsby, G.T. (1991) Finite Cavity Expansion in Dilatant Soils: Loading Analysis. Geotechnique, 41, 173-183. https://doi.org/10.1680/geot.1991.41.2.173

[32] Zentar, R., Hicher, P.Y. and Moulin, G. (2001) Identification of Soil Parameters by Inverse Analysis. Computers and Geotechnics, 28, 129-144.

https://doi.org/10.1016/S0266-352X(00)00020-3 